\title{
Uncommon overoxidative catalytic activity in a new halo-tolerant alcohol dehydrogenase
}

\author{
Martina L. Contente, ${ }^{[a]}$ Noemi Fiore, ${ }^{[b]}$ Pietro Cannazza, ${ }^{[b]}$ David Roura Padrosa, ${ }^{[c]}$ Francesco \\ Molinari, ${ }^{[b] *}$ Louise Gourlay, ${ }^{[\mathrm{d}]}$ Francesca Paradisi ${ }^{[a, c] *}$
}

[a] Dr. M. L. Contente, Prof. F. Paradisi

School of Chemistry

University of Nottingham

University Park, Nottingham, NG7 2RD, UK

[b] N. Fiore, P. Cannazza, Prof. F. Molinari

Department of Food, Environmental and Nutritional Sciences (DeFENS)

University of Milan

via Mangiagalli 25, 20133 Milan, Italy

E-mail: francesco.molinari@unimi.it

[c] Dr. D. Roura Padrosa, Prof. F. Paradisi

Department of Chemistry and Biochemistry

University of Bern

Freiestrasse 3, 3012 Bern, Switzerland

E-mail: francesca.paradisi@dcb.unibe.ch

[d] Dr. Louise Gourlay

Department of Biosciences (DBS),

University of Milan

via via Celoria 26, 20133 Milan, Italy

Supporting information for this article is given via a link at the end of the document.

\begin{abstract}
Alcohol dehydrogenases $(\mathrm{ADH})$ are versatile and useful enzymes employed as biocatalysts, especially for the selective oxidation of primary and secondary alcohols, and for the reduction of carbonyl moieties. A new alcohol dehydrogenase (HeADH-II) has been identified from the genome of the halo-adapted bacterium Halomonas elongata, which proved stable in the presence of polar organic solvents and salt exposure. Unusual for this class of enzymes, $\mathrm{HeADH}-\mathrm{Il}$ lacks enantiopreference and is capable of oxidizing both alcohols and aldehydes, enabling a direct overoxidation of primary alcohols to carboxylic acids. HeADH-II was coupled with a NADH-oxidase from Lactobacillus pentosus (LpNOX) to increase the process yields and allowing recycling of the cofactor. The enzymatic oxidation of primary alcohols was also paired with in situ condensation of the intermediate aldehydes with hydroxylamine to prepare the corresponding aldoximes, with particular attention to perillartine (a powerful sweetener), whose enzymatic synthesis starting from natural sources, leads to an equally natural product.
\end{abstract}

\section{Introduction}

Alcohol dehydrogenases (ADHs) have acquired increasing interest as versatile chemo- and enantioselective biocatalysts. ${ }^{[1-3]}$ While classic ADH-mediated oxidation of alcohols to the corresponding carbonyl compounds are well known, ${ }^{[4-6]}$ just a few examples of complete (primary) alcohol oxidation to carboxylic acids have been reported to date, often involving complex cascade enzymatic reactions. ${ }^{[7-9]}$ The identification of novel biocatalysts capable of overoxidative activity towards primary alcohols under mild conditions is essential for green and sustainable chemistry. ${ }^{[8]}$ Classically, the oxidation of primary alcohols is chemoselective and leads to the exclusive formation of aldehydes. Further oxidation is generally obtained by coupling ADHs with an aldehyde dehydrogenase (AldDH) or by using whole cell systems, such as acetic acid bacteria. ${ }^{[10,11]}$ Alcohol oxidases represent another way to access aldehydes and ketones starting from primary and secondary alcohols, respectively. In these reaction, molecular oxygen is reduced to hydrogen peroxide. In order to avoid enzyme deactivation, a second enzyme (e.g. catalase) is usually added, particularly on preparative scale. ${ }^{[12,13]}$ However, oxidation of aldehydes via ADH has been observed with horse liver dehydrogenase (HLADH), which catalyzes the dismutation of short-chain aliphatic aldehydes, in the presence of an excess of NAD ${ }^{+}{ }^{[6]}$ The complex HLADH-NAD firstly performs the oxidation of the aldehyde generating the carboxylic acid, while the newly formed complex (HLADH-NADH) binds another aldehyde molecule, catalyzing its reduction to alcohol. In this equilibrium, the hydration of the aldehyde plays an important role since the free form is the substrate for reduction, whereas the hydrate gem-diol is the actual substrate for oxidation. With simple aliphatic aldehydes, which freely interconvert between the two forms (free and gem-diol one), an equivalent amount of alcohols and carboxylic acids is formed at the end of the process with $\mathrm{HLADH}$, thus promoting an enzymatic Cannizzaro reaction. ${ }^{[7]}$ Könst et al. screened 70 different ADHs and only 9 showed significant accumulation of acid, demonstrating that this activity is rather an exception. ${ }^{\left[{ }^{[9]}\right.}$ In particular, a mutant $\mathrm{ADH}(\mathrm{ADH}-9 \mathrm{~V} 1)$, with lower binding affinity towards NADH than the wild-type enzyme, was able to better catalyze aldehyde oxidation. 
The conversion was further increased by recycling the cofactor with an $\mathrm{H}_{2} \mathrm{O}$-forming $\mathrm{NAD}(\mathrm{P}) \mathrm{H}$-oxidase (NOX) from Lactobacillus sanfranciscensis and performing the reaction at $\mathrm{pH} 9.0$ where a higher amount of $g e m$-diol is present. Under optimized conditions $(21$ h), $A D H-9 V 1$ catalyzed the oxidation of primary alcohols into carboxylic acids with conversions ranging from 9 to $37 \%$ for aromatic substrates, and $70-73 \%$ for simple aliphatic alcohols. ${ }^{[9]}$

New enzymes with improved solvent tolerance may be found in extremophiles. ${ }^{[14]} \mathrm{ADH}$ s with greater stability towards polar organic solvents have been expressed from halophilic microorganisms ${ }^{[15]}$ and from amplified genomes from unculturable species occurring in brine pool. ${ }^{[16,17]}$ In this work, an ADH gene $(\mathrm{HeADH}-\mathrm{II})$ identified from the genome of Halomonas elongata was codon optimized and expressed in E. coli; Halomonas elongata is a halo-adapted bacterium which has been previously used as source of enzymes with remarkable solvent-tolerance and stability under operating conditions.[18-21] $\mathrm{HeADH}-\mathrm{II}$ was characterized and used as biocatalyst, proving its ability to oxidize both primary alcohols and aldehydes, showing enhanced stability towards water-miscible co-solvents (e.g., DMSO).

Size exclusion chromatography indicated that the enzyme assembles as a tetramer, and in-silico modelling (together with a preliminary low-resolution crystal structure), suggests that $\mathrm{HeADH}-\mathrm{Il}$ exhibits the canonical monomeric fold of the zinc-dependent ADHs (See Supporting Information). Comparison of the overall fold revealed similarities with ADH enzymes of mammalian origin that also catalyze alcohol overoxidations.

\section{Results and Discussion}

The activity and stability of HeADH-II were firstly evaluated using the reduction of cinnamaldehyde to cinnamyl alcohol as standard reaction (See Supporting Information). The highest activity of $\mathrm{HeADH}-\mathrm{II}$ was found at $\mathrm{pH} 5.0$ in a temperature range of $45-65{ }^{\circ} \mathrm{C}$. The presence of salts has been well tolerated; the highest activity was surprisingly recorded in the presence of $3 \mathrm{M} \mathrm{NaCl}$; remarkably, the addition of DMSO had minor effect on the enzyme performance since only $8 \%$ of the original activity was lost in the presence of $10 \%$ $(v / V)$ DMSO, and just $18 \%$ with $20 \%(v / V)$ of the same co-solvent. The highest stability was found at $25{ }^{\circ} \mathrm{C}$ and $\mathrm{pH} 8.0$; high stability was also observed in the presence of $\mathrm{NaCl}$ and $\mathrm{KCl}$ and DMSO (10-20\%), confirming the possibility of using HeADH-II with watermiscible co-solvents or relatively high salt concentrations.

Reduction of cinnamaldehyde $(20 \mathrm{mM})$ into cinnamyl alcohol, with a stoichiometric amount of $\mathrm{NADH}$, was carried out at $\mathrm{pH} 8.0$, $30^{\circ} \mathrm{C}$ (best compromise between activity and stability) in the presence of $\mathrm{HeADH}-\mathrm{II}(1 \mathrm{U} / \mathrm{mL})$, showing $65 \%$ molar conversion. Relatively high concentrations of DMSO (15\%) were used to better solubilize cinnamaldehyde, which is only slightly soluble in water (1.05 g/L, 8 $\mathrm{mM}$ at $\left.20^{\circ} \mathrm{C}\right) .{ }^{[22]}$

The reverse reaction (oxidation of cinnamyl alcohol) was performed in the presence of stoichiometric amounts of $\mathrm{NAD}^{+}$at different $\mathrm{pHs}$. Oxidation generally occurred with formation of cin-namaldehyde and, unexpectedly, cinnamic acid, albeit with low conversion of the substrate (Scheme 1). To increase the yields of the oxidations, bioconversions were carried out with $\mathrm{HeADH}-\mathrm{II}(1 \mathrm{U} / \mathrm{mL})$ in the presence of $\mathrm{NAD}^{+}(0.1-10 \mathrm{mM})$, a NADH-oxidase from Lactobacillus pentosus (LpNOX) (10 U/mL) and FAD (0.1 mM) (Scheme 1).

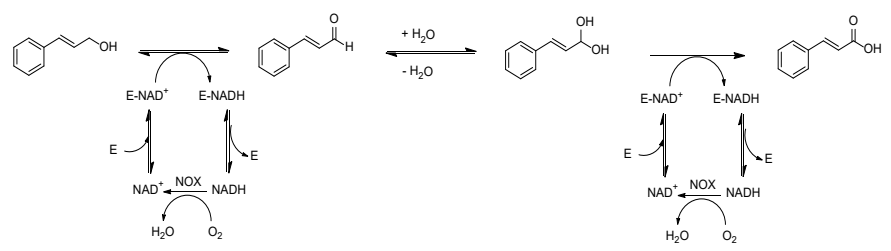

Scheme 1. Oxidation of cinnamyl alcohol and cinnamaldehyde with cofactor recycling

To combine the two different enzymes in an one-pot reaction, the reaction conditions were set so that also $L p N O X$ (employed to re-oxidize the cofactor) could optimally perform; $L p N O X$ is active between $\mathrm{pH} 5.0-9.0$ and $25-50{ }^{\circ} \mathrm{C} .{ }^{[23]}$ Therefore, preparative oxidation of both cinnamyl alcohol and cinnamaldehyde were firstly carried out at different $\mathrm{pHs}(5.0-8.0)$ and $30{ }^{\circ} \mathrm{C}$. The reaction leads to the accumulation of aldehyde, as also seen in the experiments without cofactor regeneration with a maximum conversion around $93-95 \%$, while cinnamic acid was produced only in small amounts. The biotransformation did not proceed further after the apparent equilibrium was reached within one hour, regardless of the medium $\mathrm{pH}$. This behavior may be ascribed to the low stability of $L p N O X$, with

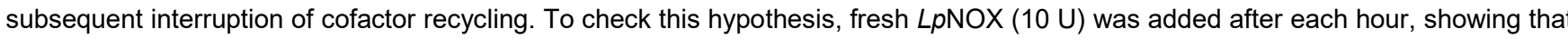
oxidation proceeded to carboxylic acid with conversions up to 99\% (See Supporting Information Figure S3), again independently of the $\mathrm{pH}$.

The oxidative reaction with fed-batch addition of $L p N O X$ was then applied to different aromatic alcohols and aldehydes (Table 1). 
The bioconversion of benzyl alcohol derivatives (Entries 2-4, Table 1) occurred in a manner similar to what was observed with cinnamyl alcohol, with an initial accumulation of aldehyde and complete oxidation into carboxylic acids with fed-batch addition of $L p N O X$. For fast-reacting substrates (Entries 5-7, Table 1), acid formation was complete in short timescales without further addition of $L p N O X$. Surprisingly, despite the short reaction time, no trace of enantioselectivity was observed with racemic 2-phenyl-1-propanol (Entry 7), which was completely oxidized in 3 hours obtaining the corresponding acid as racemate. With respect to the previous reported methodology, involving a mutated $\mathrm{ADH}$ with lower affinity for $\mathrm{NADH},{ }^{[9]}$ the new strategy allows a 4-fold higher substrate loading (20 $\mathrm{mM}$ ) while the aromatic acids were obtained with greater yields and in shorter reaction times.

To further investigate the substrate scope of this new enzyme, secondary alcohols were also tested under the above described reaction conditions (Figure 1); no fed-batch addition of LpNox was necessary. Virtually all reported ADHs display a strong enantiopreference towards either $R$ or $S$ secondary alcohols, ${ }^{[24]}$ but while HeADH-II showed activity towards $(R, S)$-1-phenyl ethanol (1a, Figure 1,65\% m.c., 2 h), a standard substrate for this enzymatic class, no enantiopreference was observed. No conversion was obtained with the bulkier $(R, S)$-1-phenyl-2-propanol (1b, Figure 1).

1a<smiles>CC(O)c1ccccc1</smiles>

$100 \mathrm{mM}$ Tris-HCl pH 8.0 $15 \%(\mathrm{v} / \mathrm{v})$ DMSO
recycling via LpNOX NAD<smiles>CC(=O)c1ccccc1</smiles>

$1 \mathrm{~b}$<smiles>CC(O)Cc1ccccc1</smiles><smiles>CC(=O)Cc1ccccc1</smiles>

No conversion

Figure 1. Oxidation of secondary alcohols using HeADH-II. Reaction conditions: $20 \mathrm{mM}$ substrate in DMSO (15\% v/v), $0.1 \mathrm{mM} \mathrm{NAD}{ }^{+}, 0.1 \mathrm{FAD}, \mathrm{HeADH}-\mathrm{Il}(1 \mathrm{U} / \mathrm{mL})$, LpNOX (10 U/mL), in Tris-HCl buffer $100 \mathrm{mM}, \mathrm{pH} 8.0$ at $30^{\circ} \mathrm{C}$.

$\mathrm{HeADH}-\mathrm{Il}$ was assayed also in the reductive direction with acetophenone $(20 \mathrm{mM})$ in the presence of a stoichiometric amount of $\mathrm{NADH}$. Again, the enzyme showed no enantioselectivity and the corresponding 1-phenyl ethanol was obtained as a completely racemic product ( $70 \%$ m.c., $6 \mathrm{~h}$ ) (See Supporting information).

Table 1. Oxidation of different primary alcohols using $\mathrm{HeADH}-\mathrm{II}$.

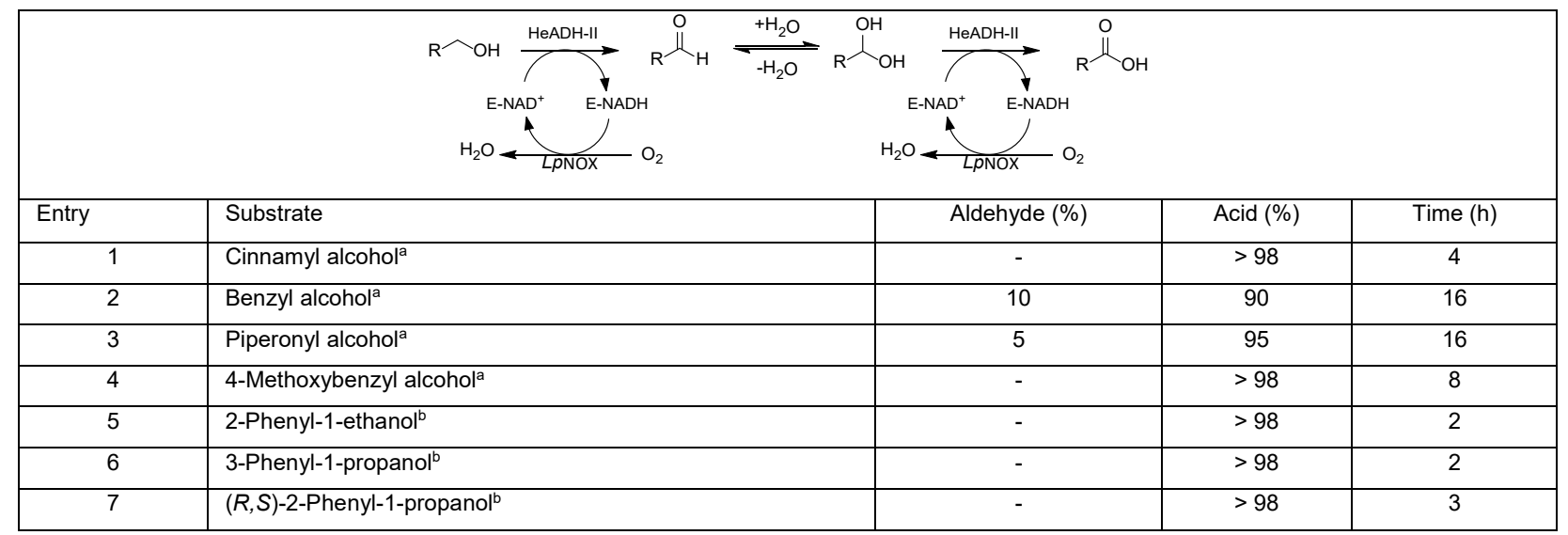

Reaction conditions: a) $20 \mathrm{mM}$ substrate in DMSO (15\% V/v), $0.1 \mathrm{mM} \mathrm{NAD}+0.1 \mathrm{mM} \mathrm{FAD,} \mathrm{HeADH-II} \mathrm{(1} \mathrm{U/mL)} \mathrm{in} \mathrm{Tris-HCl} \mathrm{buffer} 100 \mathrm{mM}$, pH 8.0, fed-batch addition of $L p N O X(10 \mathrm{U})$ every hour; b) $20 \mathrm{mM}$ substrate in DMSO (15\% V/v), $0.1 \mathrm{mM} \mathrm{NAD}+0.1 \mathrm{mM} \mathrm{FAD,} \mathrm{HeADH-II} \mathrm{(1} \mathrm{U/mL),} \mathrm{LpNOX} \mathrm{(10} \mathrm{U/mL),} \mathrm{in} \mathrm{Tris-HCl} \mathrm{buffer} 100$ $\mathrm{mM}, \mathrm{pH} 8.0$ at $30^{\circ} \mathrm{C}$. 
Table2. Oxidation of different aldehydes using $\mathrm{HeADH}-\mathrm{II}$.

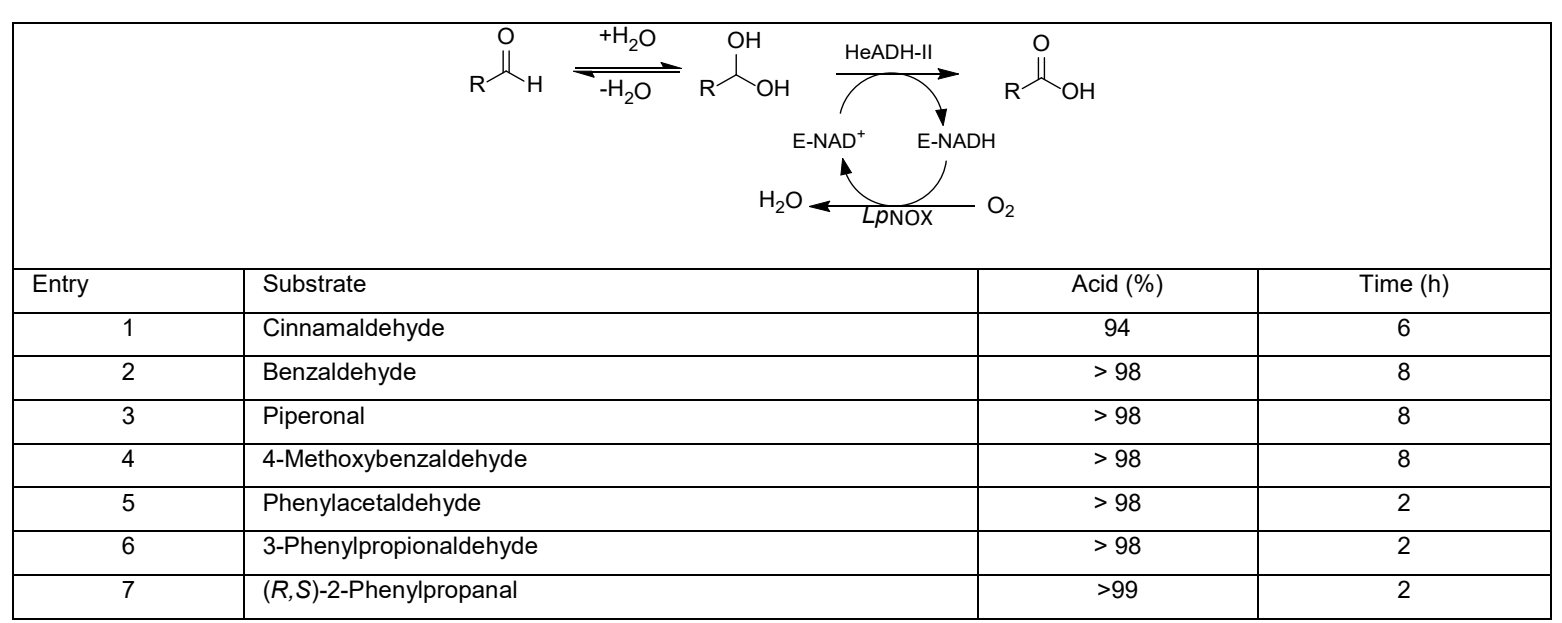

Reaction conditions: $20 \mathrm{mM}$ substrate in DMSO (15\% v/v), $0.1 \mathrm{mM} \mathrm{NAD}+0.1 \mathrm{mM} \mathrm{FAD,} \mathrm{HeADH-II} \mathrm{(1} \mathrm{U/mL),} \mathrm{LpNOX} \mathrm{(10} \mathrm{U/mL),} \mathrm{in} \mathrm{Tris-HCl} \mathrm{buffer} 100 \mathrm{mM}, \mathrm{pH} 8.0$ at $30^{\circ} \mathrm{C}$. Reaction volume $7-10 \mathrm{~mL}$.

$\mathrm{HeADH}-\mathrm{Il}$ was subsequently employed for the direct oxidation of aldehydes into the corresponding carboxylic acids with high conversion (Table 2).

Aldehyde oxidation was generally rapid, and no further addition of $L p N O X$ was necessary to obtain high yields in short reaction times. Transient formation of aldehydes in the two-step enzymatic oxidation of primary alcohols at pH 8.0 led us to explore the possibility of condensing the intermediate aldehydes with hydroxylamine, thus furnishing the corresponding aldoximes. ${ }^{[25]}$ One-pot preparation of aldoximes from primary alcohols is an interesting methodology to trap aldehydes which often present a poor stability limiting their production in high yields. ${ }^{[26,27]}$ In this instance, three different substrates were selected (Table 3 ).

Table3. Oxidation of primary alcohols using $\mathrm{HeADH}-\mathrm{II}$ in the presence of $\mathrm{NH}_{2} \mathrm{OH}$.

\begin{tabular}{|c|l|c|c|}
\hline \multicolumn{3}{|l|}{ Aldoxime (\%) } & Time (h) \\
\hline Entry & Substrate & 86 & 3 \\
\hline 1 & Cinnamyl alcohol & 86 & 6 \\
\hline 2 & Benzyl alcohol & 82 & 2 \\
\hline 3 & Perillyl alcohol & & $\mathrm{O}_{2}$ \\
\hline
\end{tabular}

Reaction conditions: $20 \mathrm{mM}$ substrate in DMSO (15\% v/v), $\mathrm{NH}_{2} \mathrm{OH} \cdot \mathrm{HCl}(24 \mathrm{mM}), 0.1 \mathrm{mM} \mathrm{NAD}+0.1 \mathrm{mM} \mathrm{FAD,} \mathrm{HeADH}-\mathrm{Il}(1 \mathrm{U} / \mathrm{mL}), \mathrm{LpNOX}(10 \mathrm{U} / \mathrm{mL})$, in Tris-HCl buffer $100 \mathrm{mM}, \mathrm{pH} 8.0$ at $30^{\circ} \mathrm{C}$. Reaction volume $7-10 \mathrm{~mL}$.

The biotransformations performed in the presence of $\mathrm{NH}_{2} \mathrm{OH}$ allowed the recovery of the aldoximes with conversions $>80 \%$. It should be noted that aldoximes have a wide range of applications as intermediates in organic synthesis. They can be reduced to amines, ${ }^{[28]}$ oxidized to nitrile oxides, ${ }^{[29]}$ and undergo a Beckman rearrangement leading to the corresponding amides. Finally, aldoximes can be converted to nitriles through a dehydration reaction. ${ }^{\left[{ }^{30]}\right.}$ Synthesis of perillartine from perillyl alcohol (Entry 3 , Table 3 , Scheme 2) was investigated as a molecule of interest in the food industry. It is typically employed as non-protein sweetener since it is 2000 -fold sweeter than sucrose. Perillartine is usually chemically prepared, starting from perillaldehyde extracted from plants (e.g., Perilla frutescens). ${ }^{[1]}$ Particular attention to the synthesis of this compound was promoted by the need to develop natural processes for the preparation of food additives: the obtainment of perillartine through the enzymatic conversion of a natural substrate allows to label and commercialize the corresponding product as natural too, thus increasing its market value.

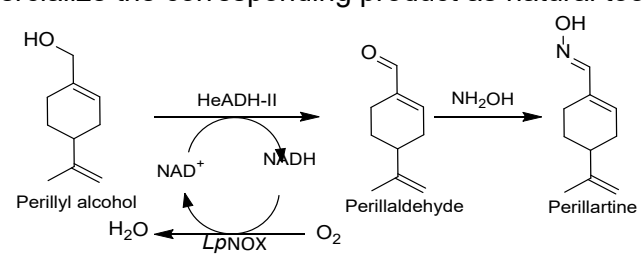


The one-pot enzymatic synthesis of perillartine was carried out also on a larger $50 \mathrm{~mL}$ scale, maintaining a $20 \mathrm{mM}$ substrate concentration. After $2 \mathrm{~h}$ biotransformation the final product was recovered with $78 \%$ of isolated yield.

\section{The 3D structure of HeADH-II: in silico modelling}

In order to understand the structural arrangement of $\mathrm{HeADH}-\mathrm{Il}$ that may explain its peculiar overoxidative activity, a model was created with MODELLER, ${ }^{[32]}$ using as query the holo-form of the bacterial ADH from Brucella melitensis (BmADH, PDB entry $3 \mathrm{MEQ}$ ) which has over $70 \%$ sequence identity and is also a tetramer, as observed for $\mathrm{HeADH}-\mathrm{Il}$ in solution by size exclusion chromatography studies (See Supporting Information Figure S6). In addition, a preliminary crystal structure of the apo-HeADH-II was achieved at low resolution (See Supporting Information Figure S8 and S9).

\section{The He-ADH-II active site analysis: overoxidation ability and enantioselectivity}

The HeADH-II chain contains two zinc ions bound at each subdomain (See Supporting Information Figure S8 and Figure S9). The catalytic zinc cation, involved in substrate binding, is bound at the nucleotide binding subdomain surrounded by C42, C152, T44 and $\mathrm{H67}$. Another residue in close vicinity to the zinc binding site is E66. Interestingly, the involvement of a glutamate in zinc coordination was observed as an atypical feature in human liver XX ADH (PDB entry 1TEH). In agreement with the overoxidative activities of HeADHII, the human enzyme catalyzes substrate oxidation of long-chain alcohols, and also S-hydroxymethyl-glutathione. ${ }^{[33]}$

$\mathrm{HeADH}-\mathrm{II}$ and human liver XX ADH share a low sequence identity of $28.9 \%$ (for 304/380 fitted residues), and a structural identity of $99.7 \%$ (See Supporting Information Figure S8), although the local sequence identity (41 equivalenced residues) surrounding the three matched active site residues, increases to $48.8 \%$, reflecting increased conservation in this region.

Direct coordination of E68 (human XX $\mathrm{ADH}$ ) has been proposed to represent a reaction intermediate that assists in product release and the water exchange step during catalysis. Accordingly, this glutamate is replaced by a coordinating water molecule in chain A of the human $X X A D H$. The resolution of our data, however, was not sufficient to visualize water molecules.

The oxidation of long-chain alcohols, accommodated by a larger than usual active site in human liver XX ADH, is suggested to occur via a catalytic mechanism similar to that of class I ADH that requires a significant decrease in the pKa of the alcohol substrate due to direct coordination with the zinc ion. As observed upon superposition of the two enzymes, HeADH-II also has a comparably large active site (See Supporting Information Figure S8). The catalytic mechanism of human liver XX ADH is proposed to employ $\mathrm{H} 47$ (H67 in $\mathrm{HeADH}-\mathrm{II}$ ) as the catalytic base, with a double role also in $\mathrm{NAD}(\mathrm{H})$ binding. During the mechanism, a proton-relay pathway is suggested, involving transfer of the substrate's hydroxyl proton, with passage from inside the active site to the solvent. In class I ADHs, mutagenesis studies have shown that the proton relay is mediated by residues T48 (T44 in HeADH-II), the 2'-hydroxyl of the nicotinamide ribose in $\operatorname{NAD}(\mathrm{H})$, and the imidazole of His47, with the latter acting as the catalytic base in the reaction. Given the sequence and structural conservation of analogous residues in $\mathrm{HeADH}-\mathrm{II}$, a similar mechanism remains to be elucidated.

Concerning horse liver ADH (HLADH), the zinc coordinating cysteines and histidine residues were matched (local sequence ID $35.7 \%$ over 41 equivalenced residues); a coordinating glutamate was not observed in the structure of HLADH, although the authors predicted its role computationally. ${ }^{[34]}$ The authors also predicted the role of S48 (T44 in HeADH-II) in proton shuttling.

As mentioned, ADHs normally exhibit very high enantioselectivities, closely related to the shape and size of the catalytic cleft which tends to display clearly differentiated small and large pockets. Such architecture favors efficient binding of just one stereoisomer (in the oxidative direction), and promotes the hydride transfer only to one face of the carbonyl molecule (in the reductive direction). ${ }^{[5]}$ In contrast, HeADH-II appears to lack any enantiopreference with the tested substrates in either catalytic direction. Only a few wild-type $\mathrm{ADHs}$ have been found to have reduced enantiopreference ${ }^{[36,37]}$ while protein engineering can lead to a less selective variants. ${ }^{[38-40]}$ The catalytic cleft of $\mathrm{HeADH}-\mathrm{Il}$ appears to be symmetric, with undistinguishable pockets, unlike the majority of ADH structures reported (including that of $\mathrm{BmADH}) .{ }^{[37]}$ To illustrate the differences in the catalytic cleft, RCR $((R)$-selective carboxyl reductase from Candida parapsilosis) and TeSADH (non-enantioselective secondary alcohol dehydrogenase from Thermoanaerobacter ethanolicum) were compared to HeADH-II. ${ }^{[1,42]}$ Despite a less than $30 \%$ of sequence homology (See Supporting Information, Figure S10A), the three enzymes exhibit a similar folding and a very similar architecture of the active site (See Supporting Information, Figure S10B), mainly differing in the size of their pockets (Figure 2A). In RCR, the two pockets are clearly distinguishable with a small pocket limited by F285 and W286. Upon mutation to alanine of either of those (F285A or W285A), the additional space causes the loss of enantioselectivity for $(R, S)$-2-phenyl-1-propanal. ${ }^{[41]}$ The HeADH-II quasi symmetric catalytic site displays a 1290 and a V291 which leave enough space in the upper pocket for bulky substituent (Figure 2B). In addition, T44 and specially the orientation of W91, extend the size of the other pocket, which mimics RCR and TeSADH. Both positions have been previously probed to investigate the stereoselectivity of HLADH. ${ }^{39]}$ Specifically, the presence of a phenylalanine in the corresponding W91 position, oriented towards the catalytic site, reduces the size of the pocket (See Supporting information, Figure S11). Notably, W91 in HeADH-II appeared to be quite static during the short MD simulation, staying parallel to the opening of the catalytic cleft, as in TeSADH. 
Docking studies of HeADH-II with both $(R)$ - and (S)-1-phenylethanol were performed; both enantiomers could be fitted in the active site with identical energies, very similar conformations, and catalytically plausible orientations (Figure 2B).

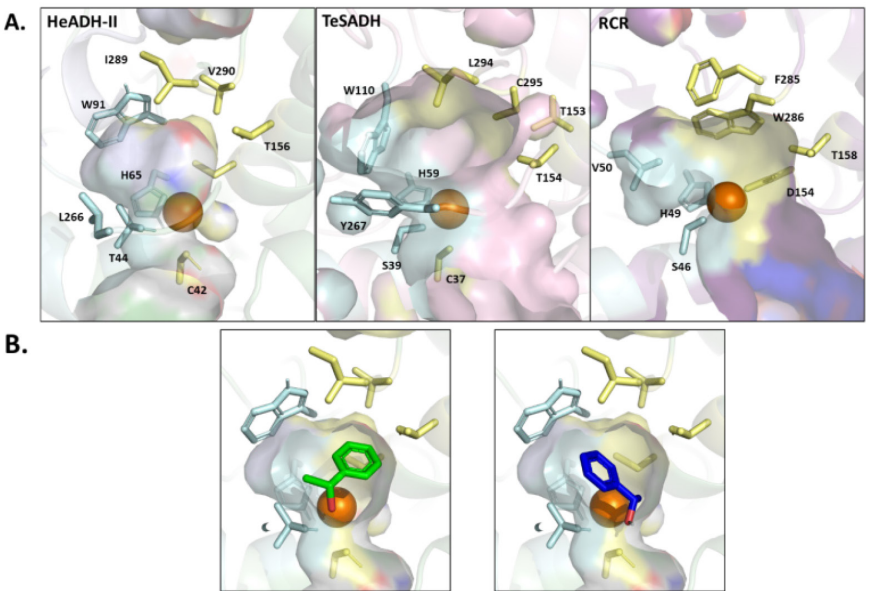

Figure 2. A) Comparison of the catalytic pockets of HeADH-II, TeSADH and RCR. The labelled residues which are defining each of the pockets are coloured in light cyan or yellow and their surface is shown. B) Detail of the docking of $(R)$ - and $(S)$ - 1-phenylethanol. The $S$ enantiomer is shown in blue and the $R$ in green. The docking energies obtained were $-5.4 \mathrm{kcal} / \mathrm{mol}$ and $-5.6 \mathrm{kcal} / \mathrm{mol}$, respectively.

\section{Conclusion}

We successfully characterized and applied a promiscuous halophilic $\mathrm{ADH}(\mathrm{HeADH}-\mathrm{II})$ that can oxidize both alcohols and aldehydes to the corresponding carboxylic acid. Based on observations made between the crystal structure of HeADH-II, it shares structural characteristics with mammalian $\mathrm{ADH}$ s that also carry out oxidative reactions. Such structural similarities and common functional activities may imply a shared catalytic mechanism, although further studies are required. This new enzyme demonstrated great activity and stability at high salt and polar solvent concentrations, usually employed for solubilizing organic compounds in water media. Enzymes derived from extremophiles, such as the halo-adapted bacterium Halomonas elongata, are particularly suitable for industrial processes thanks to their adaptation to harsher reaction environments. $\mathrm{HeADH}-\mathrm{Il}$ showed broad substrate specificity: different aromatic primary alcohols and aldehydes were fully converted to the final carboxylic acid. Moreover, the oxidation of racemic 1-phenylethanol to the corresponding ketone was obtained with good conversion, thus demonstrating enzyme versatility. Interestingly, with this substrate, no enantiopreference was observed; the lack of enantioselectivity was confirmed also when the enzyme was used for the reduction of acetophenone. This uncommon characteristic could be explained by the symmetry observed in the catalytic pockets of HeADH-II which allows both $(R)$ - and $(S)$-1-phenyl ethanol to fit as a mirror images in a catalytically plausible conformation. While the substrates tested in this work are limited, considering that no conversion was obtained with $(R, S)$-1-phenyl-2-propanol, HeADH-II could be included with only a few other examples in the list of non-stereoselective ADHs for the tested substrates which could offer major advantages in hydrogen borrowing cascades for the synthesis of chiral amines from the racemic alcohols. ${ }^{[43]}$

To further optimize the process, in situ recycling of the cofactor was performed by adding a second enzyme (LpNOX) that allowed the generation of a self-sustaining enzymatic system with the use of catalytic amounts of NAD+. Unfortunately, the NADH-oxidase from Lactobacillus pentosus ( $L \mathrm{pNOX}$ ) was found to be unstable at prolonged reaction times, so fed-batch experiments were carried out to obtain a two-step transformation with almost complete conversion. Further applications particularly focused on the enzymatic preparation of perillartine (deriving from the condensation of aldehydes with hydroxylamine) were performed. This reaction proceeds at room temperature and under the atmospheric pressures. Using an NAD+ regenerating system, catalytic amount of the cofactor could be employed. As the only by-product is water, this system can be considered sustainable and applicable for the preparation of natural food ingredients.

\section{Experimental Section}

\section{General}


NMR spectra were recorded on a Varian Gemini $300 \mathrm{MHz}$ spectrometer using the residual signal of the deuter-ated solvent as internal standard. ${ }^{1} \mathrm{H}$ chemical shifts $(\delta)$ are expressed in ppm, and coupling constants $(J)$ in hertz $(\mathrm{Hz})$. Merck Silica gel 60 F254 plates were used for analytical TLC; flash column chromatography was performed on Merck Silica gel (200-400 mesh).

\section{Chemicals}

All reagents and solvents were obtained from commercial suppliers and were used without further purification.

\section{Cloning, expression and purification}

The synthetic gene encoding for HeADH-II from Halomonas elongata, directly cloned into vector pET-28b(+) was purchased from BaseClear. The gene, optimized for the expression in E. coli, presented an $\mathrm{N}$-terminal his-tag. The resulting pET28b-HeADH-II was transformed into chemically competent $E$. coli BL21 (DE3) pLYsS for heterologous expression. Plates of E. coli BL21 (DE3) pLYsS pET28b-HeADH-Il were grown overnight at $37{ }^{\circ} \mathrm{C}$ in LB-agar medium supplemented with $25 \mu \mathrm{g} / \mathrm{mL} \mathrm{kanamycin}$ and $35 \mu \mathrm{g} / \mathrm{mL}$ chloramphenicol. $200 \mathrm{~mL}$ of autoinduction medium: $10 \mathrm{~g} / \mathrm{L} \mathrm{N}-\mathrm{Z}$ amine, $5 \mathrm{~g} / \mathrm{L}$ yeast extract, $50 \mathrm{~mL} \mathrm{KH}_{2} \mathrm{PO}_{4} 1 \mathrm{M}, 50 \mathrm{~mL} \mathrm{~K} \mathrm{HPO}_{4} 1 \mathrm{M}$, $25 \mathrm{~mL}\left(\mathrm{NH}_{4}\right)_{2} \mathrm{SO}_{4} 1 \mathrm{M}, 2 \mathrm{~mL} \mathrm{MgSO}_{4} 1 \mathrm{M}, 2 \mathrm{~mL}$ trace element solution (FeSO $50 \mathrm{mM}, \mathrm{CaCl}_{2} 20 \mathrm{mM}, \mathrm{MnCl}_{2} 10 \mathrm{mM}, \mathrm{ZnSO} 410 \mathrm{Mm}_{4}$ $\left.\mathrm{CoCl}_{2} 2 \mathrm{mM}, \mathrm{CuCl}_{2} 2 \mathrm{mM}, \mathrm{NiCl}_{2} 2 \mathrm{mM}, \mathrm{HCl} 60 \mathrm{mM}, \mathrm{NaMoO}_{4} 2 \mathrm{mM}, \mathrm{H}_{3} \mathrm{BO}_{3} 2 \mathrm{mM}\right), 20 \mathrm{~mL} 5052$ solution $(250 \mathrm{~g} / \mathrm{L}$ glycerol, $25 \mathrm{~g} / \mathrm{L}$ glucose, $100 \mathrm{~g} / \mathrm{L}$ a-lactose), $25 \mu \mathrm{g} / \mathrm{mL}$ kanamycin, $35 \mu \mathrm{g} / \mathrm{mL}$ chloramphenicol) were inoculated with a single colony. The cultures were further incubated for $16 \mathrm{~h}$ at $37^{\circ} \mathrm{C}, 120 \mathrm{rpm}$. Cells were then harvested by centrifugation $\left(15 \mathrm{~min}, 5000 \mathrm{rpm}, 4^{\circ} \mathrm{C}\right)$, washed once with deionized water and stored at $-20^{\circ} \mathrm{C} ; 10 \mathrm{~g}$ of pellet were resuspended in $50 \mathrm{~mL}$ loading buffer (Tris- $\mathrm{HCl} 100 \mathrm{mM} \mathrm{pH} 8.0$, imidazole 20 $\mathrm{mM}, \mathrm{NaCl} 100 \mathrm{mM}$ ) and sonicated ( 6 cycles of $2 \mathrm{~min}$ each, in ice, with $1 \mathrm{~min}$ interval). Cell debris were harvested by centrifugation (45 min, $15000 \mathrm{rpm}, 4^{\circ} \mathrm{C}$ ). Chromatography was performed using ÄKTA Purifier (GE Healthcare) with a $1 \mathrm{~mL}$ column HisTrapTM FF (GE Healthcare) pre-loaded with $\mathrm{NiSO}_{4}(100 \mathrm{mM})$. Briefly, the column was equilibrated with loading buffer and the filtered crude extract loaded; column was then washed with loading buffer; finally, the adsorbed enzyme was eluted with elution buffer (Tris- $\mathrm{HCl} 100 \mathrm{mM} \mathrm{pH}$ 8.0, imidazole $250 \mathrm{mM}, \mathrm{NaCl} 100 \mathrm{mM}$ ).

Crude extract, pellet and pure protein were analyzed by SDS-PAGE (See Supporting information, Figure S4). The fractions showing the presence of a band of the expected size $(38 \mathrm{kDa})$ were pooled, dialyzed against Tris- $\mathrm{HCl}$ buffer $100 \mathrm{mM}, \mathrm{pH} 8.0$ and stored at $4{ }^{\circ} \mathrm{C}$. Typically, starting from $10 \mathrm{~g}$ of wet cell paste, it was possible to obtain $5 \mathrm{mg}$ of pure protein.

The plasmid $\mathrm{pET} 28 \mathrm{a}(+)$ containing the gene encoding for $L p N O X$ was kindly provided by Prof. Sieber (University of München). The enzyme was expressed and purified as previously reported. ${ }^{[4]}$

Crude extract, pellet and pure protein were analyzed by SDS-PAGE (See Supporting information, Figure S5). The fractions showing the presence of a band of the expected size $(52 \mathrm{kDa})$ were pooled, dialyzed against Tris- $\mathrm{HCl}$ buffer $100 \mathrm{mM}, \mathrm{pH} 8.0$ and stored at $4{ }^{\circ} \mathrm{C}$. Typically, starting from $2 \mathrm{~g}$ of wet cell paste, it was possible to obtain $10 \mathrm{mg}$ of pure protein.

\section{HeADH-II activity assays}

Activity measurements were performed spectrophotometrically at $340 \mathrm{~nm}$ by determining the formation or depletion of NADH at $25^{\circ} \mathrm{C}$ in a half-microcuvette (total volume $1 \mathrm{~mL}$ ) for $2 \mathrm{~min}$. One unit $(U)$ of activity is defined as the amount of enzyme which catalyzes the consumption of $1 \mu \mathrm{mol}$ of $\mathrm{NAD}^{+} / \mathrm{NADH}$ per minute under reference conditions, namely $1 \mathrm{mM} \mathrm{NAD} / \mathrm{NADH}, 4 \mathrm{mM}$ cinnamyl alcohol/cinnamaldehyde, correct amount of $\mathrm{HeADH}-\mathrm{Il}$ in Tris- $\mathrm{HCl} 100 \mathrm{mM}, \mathrm{pH} 8.0$. Specific activity was $3 \mathrm{U} / \mathrm{mg}$ and $2.8 \mathrm{U} / \mathrm{mg}$, respectively.

\section{LpNOX activity assay}

Activity measurements were performed spectrophotometrically at $340 \mathrm{~nm}$ by determining the depletion of NADH at $25^{\circ} \mathrm{C}$ in a halfmicrocuvette (total volume $1 \mathrm{~mL}$ ) for $2 \mathrm{~min}$. One unit $(\mathrm{U})$ of activity is defined as the amount of enzyme which catalyzes the consumption of $1 \mu \mathrm{mol}$ of $\mathrm{NADH}$ per minute under reference conditions, namely $1 \mathrm{mM} \mathrm{NADH}$, correct amount of $L p N O X$ in Tris- $\mathrm{HCl}, 100 \mathrm{mM}, \mathrm{pH}$ 8.0. Specific activity was $50 \mathrm{U} / \mathrm{mg}$.

\section{Biotransformations}

Molar conversion and enantioselectivity towards different aromatic alcohols and aldehydes were determined by performing biotransformations at 20-mg scale, using an enzyme-coupled system ( $L p N O X)$ for cofactor recycling. Oxidations were carried out in 10-mL screw-capped test tubes with HeADH-II (1 U/mL), LpNOX (10 U/mL), NAD+ (0.1 mM), FAD (0.1 mM), substrate (20 mM), DMSO $(20 \% \mathrm{~V} / \mathrm{V})$ suspended in Tris-HCl buffer $100 \mathrm{mM} \mathrm{pH}$ 8.0. To determining conversion of the enzymatic reactions $100 \mu \mathrm{L}$ aliquots were quenched with $\mathrm{HCl} 0.1 \mathrm{M}$ at different reaction times and extracted with $100 \mu \mathrm{L}$ of AcOEt for TLC ( $n$-Hexane/AcOEt 9:1). Samples, after evaporation, were resuspended in the mobile phase for HPLC analysis (See Supporting Information). 


\section{One-pot reaction for the preparation of aldoximes}

One-pot biotransformations were carried out at 20-mg scale using $20 \mathrm{mM}$ alcohol as substrate in DMSO $(15 \% \mathrm{v} / \mathrm{v}), \mathrm{NH} \mathrm{OH}_{2} \mathrm{OH} \cdot \mathrm{HCl}(24$ $\mathrm{mM}), 0.1 \mathrm{mM} \mathrm{NAD}{ }^{+}, 0.1 \mathrm{mM} \mathrm{FAD}$, HeADH-II $(1 \mathrm{U} / \mathrm{mL}), \operatorname{LpNOX}(10 \mathrm{U} / \mathrm{mL})$, in Tris-HCl buffer $100 \mathrm{mM}, \mathrm{pH} 8.0$ at $30^{\circ} \mathrm{C} .150 \mu \mathrm{L}$ aliquots were extracted with AcOEt at different reaction times and analyzed by gas-chromatography (See Supporting Information).

\section{Acknowledgements}

This project was supported by the European Union's Horizon 2020 research and innovation programme under the Marie SkłodowskaCurie grant agreement no. 792804 AROMAs-FLOW (M. L. C.). L. J. G. was supported by Linea 2 Università degli Studi di Milano funding.

Keywords: Alcohol dehydrogenase $・$ Halomonas elongata $\bullet$ Overoxidation $・$ Biocatalysis $・$ Aldoxymes synthesis

\section{Bibliography}

[1] D. Monti, G. Ottolina, G. Carrea, S. Riva, Chem. Rev. 2011, 111, 4111-4140.

[2] Y. G. Zheng, H. H. Yin, D. F. Yu, X. Chen, X. L. Tang, X. J. Zhang, Y. P. Xue, Y. J. Wang, Z. Q. Liu, Appl. Microbiol. Biotechnol. 2017, 101, 987-1001.

[3] M. L. Contente, F. Paradisi, Nat. Catal. 2018, 1, 452-459.

[4] J. An, Y. Nie, Y. Xu, Crit. Rev. Biotechnol. 2019, 366-379.

[5] J. Liu, S. Wu, Z. Li, Curr. Opin. Chem. Biol. 2018, 43, 77-86.

[6] L. P. Olson, J. Luo, O. Almarsson, T. C. Bruice, Biochemistry 1996, 35, 9782-9791.

[7] a) C. Wuensch, H. Lechner, S. M. Glueck, K. Zangger, M. Hall, K. Faber, ChemCatChem 2013, 5, 1744-1748. b) E. Tassano, K. Faber, M. Hall, Adv. Synth. Catal. 2018, 360, 2742 - 2751.

[8] J. Dong, E. Fernandez-Fueyo, F. Hollmann, C. E. Paul, M. Pesic, S. Schmidt, Y. Wang, S. Younes, W. Zhang., Angew. Chem. Int. Ed. 2018, 57, 9238-9261.

[9] P. Könst, H. Merkens, S. Kara, S. Kochius, A. Vogel, R. Zuhse, D. Holtmann, I. W. C. E. Arends, Hollmann F., Angew. Chem. Int. Ed. 2012, 51, 9914-9917.

[10] D. Romano, R. Villa, F. Molinari, ChemCatChem 2012, 4, 739-749.

[11] D. Romano, M. Contente, T. Granato, W. Remelli, P. Zambelli, F. Molinari, Monatsh. Chem. 2013, 14, $735-737$.

[12] F. Molinari, Curr. Org. Chem. 2006, 10, 1247-1263.

[13] M. Pickl, M. Fuchs, S. M. Glueck, K. Faber, Appl Microbiol Biotechnol 2015, 99, 6617-6642.

[14] A. Trincone, Mar. Drugs 2011, 9, 478-499.

[15] D. Alsafadi, S. Alsalman, F. Paradisi, Org. Biomol. Chem. 2017, 15, 9169-9175.

[16] S. W. Grötzinger, R. Karan, E. Strillinger, S. Bader, A. Frank, I. S. Al Rowaihi, A. Akal, W. Wackerow, J. A. Archer, M. Rueping, D. Weuster-Botz, M. Groll, J. Eppinger, S. T. Arold, ACS Chem. Biol. 2018, 13, 161-170.

[17] A. L. Akal, R. Karan, A. Hohl, I. Alam, M. Vogler, S. W. Grötzinger, J. Eppinger, M. Rueping, FEBS Open Bio 2019, 9, $194-205$.

[18] L. Cerioli, M. Planchestainer, J. Cassidy, D. Tessaro, F. Paradisi, J. Mol. Catal. B: Enzym. 2015, 120, 141-150.

[19] M. Planchestainer, M. L. Contente, J. Cassidy, F. Molinari, L. Tamborini, F. Paradisi, Green Chem. 2017, 9, 372-375.

[20] D. Roura-Padrosa, V. De Vitis, M. L. Contente, F. Molinari, F. Paradisi, Catalysts 2019, 9, 232-242.

[21] M. L. Contente, F. Dall'Oglio, L. Tamborini, F. Molinari, F. Paradisi, ChemCatChem 2017, 9, 3843-3848.

[22] S. N. Ashakirin, M. Tripathy, U. K. Patil, A. B. A. Majeed, Int J. Pharm. Sci. 2017, 8, 2333-2340.

[23] A. A. Koesoema, D. M. Standley, T. Senda, T. Matsuda, Appl. Microbiol. Biotechnol. 2020, 104, 2897-2909

[24] J. D. Zhang, Z. M. Cui, X. J. Fan, H. L. Wu, H. H. Chang, Bioprocess Biosyst. Eng. 2016, 39, 603-611.

[25] P. Zambelli, A. Pinto, D. Romano, E. Crotti, P. Conti, L. Tamborini, R. Villa, F. Molinari, Green Chem. 2012, 14, $2158-2161$.

[26] H. Kanno, R. J. K. Taylor, Synlett 2002, 1287-1290.

[27] A. R. Klasat, F. Kazemi, K. Nourbakhsh Phosphorus, Sulfur, Silicon Relat. Elem., 2004, 179, 1809-1812. 
[28] P. Bandgar, S. M. Nikat, P. P. Wadgaonkar Synth Commun. 1995, 25, 863-869.

[29] B. A. Mendelsohn, S. Lee, S. Kim, F. Teysseier, V. S. Aulakh, M. A. Ciufolini, Org. Lett. 2009,11, 1539-1542.

[30] Y. T. Li, B. S. Liao, H. P. Chen, S. T. Liu, Synthesis 2011, 2639-2643.

[31] R. K. Saini, S. Sravan Kumar, S. Priyanka, K. Kamireddy, P. Giridhar in Biotechnological Production of Natural Ingredients for Food Industry, 1st ed, Bentham Science Publisher Sharjah, 2016, pp 21-59.

[32] B. Webb B, A. Sali, Curr. Protoc. Bioinformatics 2016, 54, 5.6.1-5.6.37.

[33] Z. N. Yang, W. F. Bosron, T. D. Hurley, J. Mol. Biol. 1997, 265, 330-343.

[34] L. P. Olson, J. Luo, Ö. Almarsson, T. C. Bruice, Biochemistry 1996, 35, 9782-9791.

[35] F. M. Dickinson, K. Dalziel, Nature 1967, 214, 31-33.

[36] I. Lavandera, A. Kern, V. Resch, B. Ferreira-Silva, A. Glieder, W. M. F. Fabian, S. de Wildeman, W. Kroutil, Org. Lett. 2008, 10, 2155-2158.

[37] F. Chen, Y. Liu, G. Zheng, J. Xu, ChemCatChem 2015, 7, 3838-3841.

[38] M. A. Maria-Solano, A. Romero-Rivera, S. Osuna, Org. Biomol. Chem. 2017, 15, 4122-4129.

[39] K. Kim, B. V. Plapp, Chem-Biol Interact. 2017, 276, 77-87.

[40] J. M. Patel, M. M. Musa, L. Rodriguez, D. A. Sutton, V. V. Popik, R. S. Phillips, Org. Biomol. Chem. 2014, 12, 5905-5910.

[41] S. Wang, Y. Nie, Y. Xu, R. Zhang, T. P. Ko, C. H. Huang, H. C. Chan, R. T. Guo, R. Xiao, Chem. Commun. 2014, 50, 77707772 .

[42] Y. Korkhin, A. J. Kalb, M. Peretz, O. Bogin, Y. Burstein, F. Frolow J. Mol. Biol., 1998, 278, 967-981

[43] F. G. Mutti, T. Knaus, N. S. Scrutton, M. Breuer, N. J. Turner, Science 2015, 349, 1525-1529.

[44] C. Nowak, B. Beer, A. Pick, T. Roth, P. Lommes, V. Sieber, Front. Microbiol. 2015, 6, 957-965. 


\section{Entry for the Table of Contents}

Insert graphic for Table of Contents here.

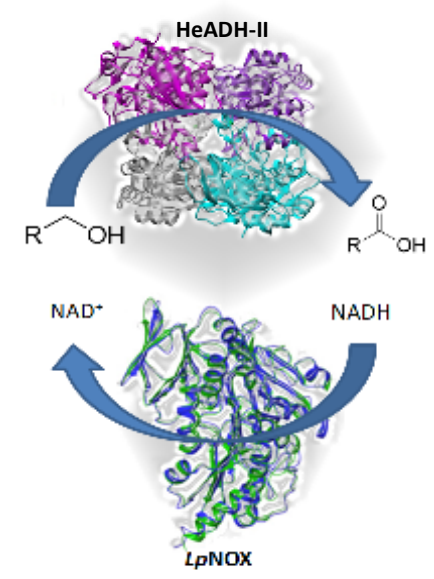

An unusual alcohol dehydrogenase has been identified from the halo-adapted bacterium $\mathrm{H}$. elongata. HeADH-II shows a great stability to polar solvents and high salt concentration as well as uncommon characteristics such as the lack of enantiopreference and the capability of overoxidizing alcohols to carboxylic acids. To increase the process yields and allowing cofactor recycling, HeADH-II was coupled with a NADH-oxidase from $L$. pentosus ( $L p N O X)$.

researcher Twitter usernames: @ParadisiResLab 